doctor. Deepest sympathy was extended to his widow and daughter, and the expression of this by the immense congregation at Old Chiswick Church.

He has left a pleasant memory, which will rather grow than dwindle with time.

\title{
Joseph Tregelles Hingston, M.R.C.S.Eng., L.S.A.
}

Dr. J. T. Hingston died within a few months of his 82 nd year on February 18 th, 1917. He obtained his Medical Diploma in 1856 and almost immediately adopted Lunacy as his special subject, leaving the Middlesex Hospital to become Assistant Medical Officer at the North Riding Asylum, York. In 1862 he went to St. Andrew's, Northampton, as Assistant, and from there in 1868 he was appointed Medical Superintendent of the Isle of Man Asylum, to remain only a couple of years before he returned in 1870 to the North Riding as Chief, which office he fulfilled for thirty-five years, retiring in 1905 on the completion of forty-nine years' Asylum service. He was a member of the Medico-Psychological Association since 1871 , and many will recall with pleasure the General and Divisional meetings held at his Asylum. Hingston throughout his lifetime endeared himself to all with whom he came in contact, by his innate old-world courtesy and his sympathetic nature. He was a fine type of the kindly, good-hearted gentleman whose thoughtfulness and consideration for others went far to alleviate their sufferings and trials.

He recognised the value of personality and moral influence in the treatment of the insane, and strongly advocated the importance of the hopeful word, cheerful surroundings, interesting employments, and amusements as a help to his patients to put aside the toil of disease and to climb the difficult and tedious path of recovery which leads to reason.

Hingston was of a retiring but cheerful disposition, and few outside his intimate friends had an opportunity of appreciating his wonderful charm of manner and keen sense of humour. On his retirement he went to reside at Leamington. For some time previous to his death he lived with his daughter and son-in-law at Acocks Green Vicarage, Birmingham. During the last few months of his illness he was subject to severe attacks of anginá, but, as ever, his thoughts were not centred on his own suffering; his fear was that he might be a trouble to those around him.

"Leave him-still loftier than the world suspects

Living and dying."

\section{Robert Brice SMyth.}

IT is with deep regret that we record the sudden death, on February 27 th, of Dr. R. B. Smyth at the early age of forty-five.

He came of an old Ulster family, and his father and surviving brother, who are also members of the medical profession, are at present in practice in Belfast.

He was educated at Uppingham and Trinity College, Dublin, and qualified in 1893, taking the degrees of M.A., M.B., B.Ch., B.A.O. In the following year he went as Clinical Assistant to St. Luke's Hospital, and in 1895 he was appointed Assistant Medical Officer at the Gloucester County Asylum, becoming Superintendent of that institution on the death of Dr. Henley in 1908.

For eight years he carried out the duties of a difficult position with marked ability, and his lovable disposition and attractive personality endeared him to all. No undertaking was too great and no detail was too small for his energies and attention, and his whole object and aim in life was the welfare, good name, and honour of the institution entrusted to his care.

From the outset he won the entire confidence of his Committee, and his affection for his patients and the extraordinary interest he took in their individual welfare were, at all times, predominant.

Dr. Smyth was a keen follower of all kinds of outdoor sport. A steady batsman and a good captain he did much for cricket in the Asylum; he also, in his younger days, played regularly for the Gloucester City team. He was a good game shot and fly fisherman, and his holidays were always spent in these latter 